\title{
Outsourcing and Optimal Nonlinear Taxation: A Note
}

\author{
Thomas Aronsson \\ Umeå University, Sweden \\ and \\ Erkki Koskela \\ University of Helsinki, RUESG and HECER
}

Discussion Paper No. 206

March 2008

ISSN 1795-0562

HECER - Helsinki Center of Economic Research, P.O. Box 17 (Arkadiankatu 7), FI-00014 University of Helsinki, FINLAND, Tel +358-9-191-28780, Fax +358-9-191-28781,

E-mail info-hecer@helsinki.fi, Internet www.hecer.fi 


\section{Outsourcing and Optimal Nonlinear Taxation: A Note*}

\section{Abstract}

The paper addresses outsourcing in the two-type optimal income tax model. If government is able to control outsourcing via a direct tax instrument, outsourcing will not affect the marginal income tax structure. In the absence of a direct tax instrument, the appearance of outsourcing, under the plausible assumption that higher outsourcing increases wage differentials, means that the government implements a lower marginal income tax rate for the low-ability type and a higher marginal income tax rate for the high-ability type than it would otherwise have done.

JEL Classification: H21, H25, J31, J62.

Keywords: Outsourcing, optimal nonlinear taxation.

Thomas Aronsson

Department of Economics

Umeå University

SE-901 87 Umeå

SWEDEN

e-mail: thomas.aronsson@econ.umu.se
Erkki Koskela

Department of Economics

University of Helsinki

P.O. Box 17 (Arkadiankatu 7)

$\mathrm{FI}-00014$ Helsinki

FINLAND

e-mail: erkki.koskela@helsinki.fi

* Aronsson thanks the Research Unit of Economic Structures and Growth (RUESG) at the University of Helsinki for good hospitality and Koskela thanks Academy of Finland (grant No.1117698) for financial support. 


\section{Introduction}

During the latest $10-15$ years, outsourcing has become an increasingly important business practice. Outsourcing is meant to imply that part of the production activity is located to another country. The large wage differences across countries is most likely an important explanation for this behavior, as the production costs may be substantially reduced if part of the production is located to a country with lower wages $^{1}$. Although earlier research has addressed the implications of outsourcing for unemployment and welfare policy ${ }^{2}$, there are (to our knowledge) no earlier studies dealing with how the appearance of outsourcing may modify the optimal use of redistributive nonlinear income taxation.

The purpose of this short paper is to incorporate outsourcing into the two-type optimal income tax model developed by Stern (1982) and Stiglitz (1982). We show that if the government is able to control outsourcing via a direct tax instrument, then outsourcing will not modify the policy rules for the marginal income tax rates. Instead, the government will use a positive tax on outsourcing, which contributes to reduce the wage inequality and, therefore, also to relax the self-selection constraint. On the other hand, if the government is not able to directly tax outsourcing, it will modify from social welfare point of view its use of income taxation accordingly. In this case, and under the plausible assumption that higher outsourcing increases wage differentials, our results show that outsourcing provides an incentive for the government to implement a lower marginal income tax rate for the low-ability type and a higher marginal income tax rate for the high-ability type than it would otherwise have done.

In Section 2, we present the model, whereas the optimal use of income taxation is discussed in Section 3. Finally, we present a brief summary in Section 4.

\footnotetext{
${ }^{1}$ See e.g. Amiti and Wei (2004), Rishi and Saxena (2004) and Sinn (2007).

${ }^{2}$ See e.g. Keuschnigg and Ribi (2007).
} 


\section{The Model}

We consider a model with two-ability types; a low-ability type (denoted by index 1) and a high-ability type (denoted by index 2). This distinction refers to productivity, which is interpreted to mean that the high-ability type faces a higher before tax wage rate than the low-ability type. As the number of individuals of each ability-type is not important here, it will be normalized to one for notational convenience. The utility function facing ability-type $i$ is written as

$$
u^{i}=u\left(c^{i}, z^{i}\right)
$$

where $c$ is consumption and $z$ leisure. Leisure is, in turn, defined as a time endowment, $H$, less the time spent in market work, $l$. The individual budget constraint is written as

$$
w^{i} l^{i}-T\left(w^{i} l^{i}\right)-c^{i}=0
$$

in which $w$ is the hourly gross wage rate and $T\left(w^{i} l^{i}\right)$ the income tax payment. The first order condition for the hours of work becomes

$$
u_{c}^{i} w^{i}\left(1-T^{\prime}\left(w^{i} l^{i}\right)\right)-u_{z}^{i}=0
$$

where $T^{\prime}\left(w^{i} l^{i}\right)=\partial T\left(w^{i} l^{i}\right) / \partial\left(w^{i} l^{i}\right)$ is the marginal income tax rate.

Turning to the production side of the economy, the representative firm uses three variable inputs, labor of each ability-type and the amount of resources outsourced to production abroad. To simplify the analysis, we assume that the technology is characterized by constant returns to scale. Following Koskela and Stenbacka (2007), the production function is written as $f\left(l^{1}, l^{2}, M\right)$, where $M$ represents the resources spent on outsourcing, where outsourcing is assumed to be substitutable for unskilled labor and complementary with skilled labor. This assumption implies $f_{l^{1} M}\left(l^{1}, l^{2}, M\right)<0$ and $f_{l^{2} M}\left(l^{1}, l^{2}, M\right)>0$. There is also a cost associated with 
outsourcing, $\psi(M)$, which is increasing and strictly convex. The first order conditions for the firm become

$$
\begin{aligned}
& f_{l^{1}}\left(l^{1}, l^{2}, M\right)-w^{1}=0 \\
& f_{l^{2}}\left(l^{1}, l^{2}, M\right)-w^{2}=0 \\
& f_{M}\left(l^{1}, l^{2}, M\right)-\psi_{M}(M)-t=0
\end{aligned}
$$

where $t$ is a tax attached to outsourcing. This policy instrument may either be operative or not in the analysis we present in Section 3.

\section{Optimal Nonlinear Taxation}

We analyze Pareto efficient taxation, which means maximizing the utility of one of the ability-types subject to minimum utility restrictions for the other. Suppose that the government behaves as if it maximizes the utility of the low-ability type subject to minimum utility restrictions for the high-ability type. The minimum utility restriction is given by

$$
u^{2}=u\left(c^{2}, z^{2}\right)-\bar{u}^{2}
$$

The informational assumptions are conventional: the government knows the income of each individual as well as the number of individuals of each agent-type, whereas ability is private information. The latter means that the government would not be able to observe whether any given worker is a low-ability or high-ability type. By concentrating on the 'normal' case, where redistribution means income transfers from the high-ability to the low-ability type, one would like to prevent the high-ability type from pretending to be a low-ability type, i.e. prevent the high-ability type from becoming a mimicker, in order to gain from the redistribution. The self-selection constraint that may bind then becomes

$$
u^{2}=u\left(c^{2}, z^{2}\right) \geq u\left(c^{1}, H-\phi l^{1}\right)=\hat{u}^{2}
$$


where $\hat{u}^{2}$ denotes the utility of the mimicker and $\phi=w^{1} / w^{2}$ the wage ratio, i.e. the relative wage rate. By using the first order conditions for the firm, one can see that $\phi$ is a function of $l^{1}, l^{2}$ and $M$, i.e. $\phi=\phi\left(l^{1}, l^{2}, M\right)$, where $\partial \phi / \partial M<0$. Note that the mimicker faces the same income and consumption point (and, therefore, pays as much tax as) the low-ability type; however, as the mimicker is more productive than the low-ability type, he/she spends more time on leisure.

The budget constraint of the government is given by

$$
\sum_{i} T\left(w^{i} l^{i}\right)+t M=0
$$

Note that $T(\cdot)$ is a general income tax in the sense that it may be used to implement any desired combination of $l^{1}, c^{1}, l^{2}$, and $c^{2}$. It is, therefore, convenient to follow earlier comparable literature by using $l^{1}, c^{1}, l^{2}$, and $c^{2}$, instead of the parameters of $T(\cdot)$, as direct decision-variables. Similarly, since control over $l^{1}, c^{1}, l^{2}$, and $c^{2}$ also means that the government can use $t$ to exercise perfect control over $M$, we may also use $M$ as a direct decision-variable in what follows. By using the private budget constraint and the zero profit condition, we may rewrite the budget constraint of the government to read

$$
f\left(l^{1}, l^{2}, M\right)-\sum_{i} c^{i}-\psi(M)=0
$$

The Lagrangean is given by

$$
L=u^{1}+\delta u^{2}+\lambda\left[u^{2}-\hat{u}^{2}\right]+\gamma\left[f\left(l^{1}, l^{2}, M\right)-\sum_{i} c^{i}-\psi(M)\right]
$$

The first order conditions in terms of hours of work, consumption and outsourcing are given by

$$
-u_{z}^{1}+\lambda \hat{u}_{z}^{2}\left[\phi+l^{1} \frac{\partial \phi}{\partial l^{1}}\right]+\gamma w^{1}=0
$$




$$
\begin{aligned}
& u_{c}^{1}-\lambda \hat{u}_{c}^{2}-\gamma=0 \\
& -(\delta+\lambda) u_{z}^{2}+\lambda \hat{u}_{z}^{2} l^{1} \frac{\partial \phi}{\partial l^{2}}+\gamma w^{2}=0 \\
& (\delta+\lambda) u_{c}^{2}-\gamma=0 \\
& \lambda \hat{u}_{z}^{2} l^{1} \frac{\partial \phi}{\partial M}+\gamma\left[f_{M}(\cdot)-\psi_{M}(M)\right]=0
\end{aligned}
$$

We are now in the position to analyze the question: how does the appearance of outsourcing affect the optimal tax structure? The marginal income tax rate of the lowability type might be derived by combining equations (3), (12) and (13), whereas the marginal income tax rate of the high-ability type is derived by combining equations (3), (14) and (15). Finally, the tax rate on outsourcing can be derived by combining equations (6) and (16). Let

$$
M R S_{z, c}^{i}=\frac{u_{z}^{i}}{u_{c}^{i}} \text { and } M \hat{R} S_{z, c}^{2} \frac{\hat{u}_{z}^{2}}{\hat{u}_{c}^{2}}
$$

be the marginal rate of substitution between leisure and private consumption for ability-type $i$ and the mimicker, respectively. We can derive

$$
\begin{aligned}
& T^{\prime}\left(w^{1} l^{1}\right)=\frac{\lambda^{*}}{w^{1}}\left[M R S_{z, c}^{1}-\phi M \hat{R} S_{z, c}^{2}\right]-\frac{\lambda}{\gamma w^{1}} \hat{u}_{z}^{2} l^{1} \frac{\partial \phi}{\partial l^{1}} \\
& T^{\prime}\left(w^{2} l^{2}\right)=-\frac{\lambda}{\gamma w^{2}} \hat{u}_{z}^{2} l^{1} \frac{\partial \phi}{\partial l^{2}} \\
& t=-\frac{\lambda}{\gamma} \hat{u}_{z}^{2} l^{1} \frac{\partial \phi}{\partial M}
\end{aligned}
$$

where $\lambda^{*}=\lambda \hat{u}_{c}^{2} / \gamma$. The marginal income tax rates are the same as those derived by Stiglitz (1982). Therefore, one would normally expect that $T^{\prime}\left(w^{1} l^{1}\right)>0$ and $T^{\prime}\left(w^{2} l^{2}\right)<0$. As the intuition behind the use of marginal income taxation is well understood from earlier research, it will not be further discussed here. 
Note that the government may also relax the self-selection constraint via the tax on outsourcing. With the assumptions made above, we have ${ }^{3} \partial \phi / \partial M<0$, which means that the optimal tax on outsourcing is positive. The intuition is that the tax on outsourcing reduces the amount of resources subject to outsourcing which, in turn, increases the wage ratio. This makes mimicking less attractive and contributes to relax the self-selection constraint. As such, the tax on outsourcing creates additional room for redistribution. In addition, since the government is able to directly control outsourcing, there is no need to modify the policy rules for marginal income taxation.

We can summarize our finding as follows;

Proposition 1. If the government is able to directly tax outsourcing, the tax on outsourcing will be positive at the second best optimum. In this case, the appearance of outsourcing will not modify the policy rules for the marginal income tax rates.

The next question is: what happens if the tax instrument on outsourcing, for some reason, is not operative? In this case, the government is not able to directly control the outsourcing via taxation, meaning that it may have an incentive to modify its use of income taxation accordingly. Let

$$
\Lambda \quad \lambda \hat{\pi}_{z}^{2} l^{1} \frac{\partial \phi}{\partial M}+f_{M}-\psi_{M}
$$

denote the marginal welfare effect of outsourcing. Furthermore, by using equation (6), we can derive $M=M\left(l^{1}, l^{2}\right)$. We have the following expressions for the marginal income tax rates;

$$
T^{\prime}\left(w^{1} l^{1}\right)=\frac{\lambda^{*}}{w^{1}}\left[M R S_{z, c}^{1}-\phi M \hat{R} S_{z, c}^{2}\right]-\frac{\lambda}{\gamma w^{1}} \hat{u}_{z}^{2} l^{1} \frac{\partial \phi}{\partial l^{1}} \underbrace{\frac{\Lambda}{\gamma w^{1}} \frac{\partial M}{\partial l^{1}}}_{-}
$$

\footnotetext{
${ }^{3}$ Empirical support for the idea that outsourcing leads to more inequality are provided e.g. by Feenstra and Hanson (1999), Hijzen, Görg and Hine (2005), Hijzen (2007) and Geishecker and Görg (2008).
} 


$$
T^{\prime}\left(w^{2} l^{2}\right)=-\frac{\lambda}{\gamma w^{2}} \hat{u}_{z}^{2} l^{1} \frac{\partial \phi}{\partial l^{2}} \underbrace{-\frac{\Lambda}{\gamma w^{2}} \frac{\partial M}{\partial l^{2}}}_{+}
$$

By comparison with equations (17) and (18), equations (20) and (21) also reflect an additional policy incentive created by the appearance of outsourcing, which is summarized by the final part on the right hand side of each marginal income tax rate expression. The intuition is that the government is no longer able to control outsourcing via a direct tax instrument, in which case it will modify its use of income taxation. Note from equation (6) that $f_{M}-\psi_{M}=0$, which means that $\Lambda<0$. In addition, by using equation (6), one can show that $\partial M / \partial l^{1}<0$ and $\partial M / \partial l^{2}>0$.

Therefore, with the assumptions made above, we have derived the following result.

Proposition 2. If the government is not able to control the outsourcing via a direct tax instrument, then the appearance of outsourcing will contribute to decrease the marginal income tax rate of the low-ability type and increase the marginal income tax rate of the high-ability type.

The intuition behind Proposition 2 is that by increasing the hours of work supplied by the low-ability type and decreasing the hours of work supplied by the high-ability type, we may reduce the amount of resources that are subject to outsourcing. The latter contributes to relax the self-selection constraint, which creates further room for redistribution.

\section{Summary}

This paper analyzes the implications of outsourcing for optimal income taxation by using the two-type optimal income tax model. Our results show that if the government is able to control outsourcing via a direct tax instrument, outsourcing will not affect the policy rules for the marginal income tax rates. Instead, the government uses a positive tax on outsourcing, which contributes to reduce the wage inequality and, therefore, also to relax the self-selection constraint. In the absence of a direct tax instrument, on the other hand, the appearance of outsourcing means that the 
government implements a lower marginal income tax rate for the low-ability type and a higher marginal income tax rate for the high-ability type than it would otherwise have done.

\section{References}

Amiti, M. and Wei, S-J. (2004) Fear of Service Outsourcing: is it Justified. NBER Working Paper no 10808.

Feenstra, R.C. and Hanson, G.H. (1999) The Impact of Outsourcing and HighTechnology Capital on Wages. Quarterly Journal of Economics 114, 907-940.

Geishecker, I. and Görg, H. (2008) Winners and Losers: A Micro-Level Analysis of International Outsourcing and Wages. Canadian Journal of Economics 41, 243270.

Hijzen, A. (2007) International Outsourcing, Technological Change, and Wage Inequality. Review of International Economics 15, 188-205.

Hijzen, A. Görg, H. and Hine, R.C. (2005) International Outsourcing and the Skill Structure of Labor Demand in the United Kingdom. Economic Journal 115, 860878.

Keuschnigg, C. and Ribe, E. (2007) Outsourcing, Unemployment and Welfare. Oxford University Centre for Business Taxation. Working paper no 07/20.

Koskela, E. and Stenbacka, R. (2007) Equilibrium Unemployment with Outsourcing and Wage Solidarity under Labor Market Imperfections, CESifo Working paper No. 1988.

Rishi, M. and Saxena, S. (2004) Is Outsourcing Really as Bad as it May Sound? Pittsburg University, working paper.

Sinn, H-W. (2007) The Welfare State and Forces of Globalization. CESifo working paper no 1925.

Stern, N.H. (1982) Optimum Taxation with Errors in Administration. Journal of Public Economics 17, 181-211.

Stiglitz, J. E. (1982) Self-Selection and Pareto Efficient Taxation. Journal of Public Economics 17, 213-240. 